\title{
Modern sedimentation patterns in Lake El'gygytgyn, NE Russia, derived from surface sediment and inlet streams samples
}

\author{
V. Wennrich ${ }^{1}$, A. Francke ${ }^{1}$, A. Dehnert ${ }^{2}$, O. Juschus ${ }^{3}$, T. Leipe ${ }^{4}$, C. Vogt $^{5}$, J. Brigham-Grette ${ }^{6}$, P. S. Minyuk ${ }^{7}$, \\ M. Melles ${ }^{1}$, and El'gygytgyn Science Party \\ ${ }^{1}$ University of Cologne, Institute for Geology and Mineralogy, Cologne, Germany \\ ${ }^{2}$ Swiss Federal Nuclear Safety Inspectorate ENSI, Brugg, Switzerland \\ ${ }^{3}$ Eberswalde University for Sustainable Development, Eberswalde, Germany \\ ${ }^{4}$ Leibniz Institute for Baltic Sea Research Warnemuende, Marine Geology, Rostock, Germany \\ ${ }^{5}$ University Bremen, Department of Geosciences, Crystallography/ZEKAM, Bremen, Germany \\ ${ }^{6}$ University of Massachusetts, Department of Geosciences, Amherst, USA \\ ${ }^{7}$ Russian Academy of Sciences, Northeast Interdisciplinary Scientific Research Institute, Magadan, Russia
}

Correspondence to: V. Wennrich (volker.wennrich@uni-koeln.de)

Received: 27 April 2012 - Published in Clim. Past Discuss.: 1 June 2012

Revised: 19 October 2012 - Accepted: 10 December 2012 - Published: 22 January 2013

\begin{abstract}
Lake El'gygytgyn/NE Russia holds a continuous 3.58 Ma sediment record, which is regarded as the most longlasting climate archive of the terrestrial Arctic. Based on multi-proxy geochemical, mineralogical, and granulometric analyses of surface sediment, inlet stream and bedrock samples, supplemented by statistical methods, major processes influencing the modern sedimentation in the lake were investigated. Grain-size parameters and chemical elements linked to the input of feldspars from acidic bedrock indicate a windinduced two-cell current system as major driver of sediment transport and accumulation processes in Lake El'gygytgyn. The distribution of mafic rock related elements in the sediment on the lake floor can be traced back to the input of weathering products of basaltic rocks in the catchment. Obvious similarities in the spatial variability of manganese and heavy metals indicate sorption or co-precipitation of these elements with Fe and Mn hydroxides and oxides. But the similar distribution of organic matter and clay contents might also point to a fixation to organic components and clay minerals. An enrichment of mercury in the inlet streams might be indicative of neotectonic activity around the lake. The results of this study add to the fundamental knowledge of the modern lake processes of Lake El'gygytgyn and its lakecatchment interactions, and thus, yield crucial insights for the interpretation of paleo-data from this unique archive.
\end{abstract}

\section{Introduction}

In spring 2009, the ICDP El'gygytgyn Drilling Project recovered the 318-m long lacustrine sediment record of Lake El'gygytgyn in Chukotka, NE Russia (Melles et al., 2011, 2012; Fig. 1). Long high-resolution lake sediment records are known to well document regional hydrologic and climatic responses to atmospheric changes (Brigham-Grette et al., 2007a), and therefore are valuable archives of climate and environmental changes (e.g. Allen et al., 1999; Gasse et al., 2011; Cohen, 2012). Given their often continuous sediment sequences, large and old lake basins play an important role in collecting sedimentological information providing a continental signature to couple with the marine realm. Thus, these lakes help to close gaps in the knowledge on land-ocean interactions through time. Nevertheless, the profound interpretation of proxy data derived from lake sediment records requires an in-depth knowledge of the lake-specific modern biological and sedimentological processes and their controlling factors (e.g. Vogel et al., 2010; Viehberg et al., 2012).

Lake El'gygytgyn represents a unique site, because it holds the most long-lasting climate archive of the terrestrial Arctic (Melles et al., 2011, 2012), reaching back to the time of meteorite impact event 3.58 Ma ago (Layer, 2000). Furthermore, the basin was never overcome by large Cenozoic continental ice-masses (Glushkova, 2001; Glushkova 


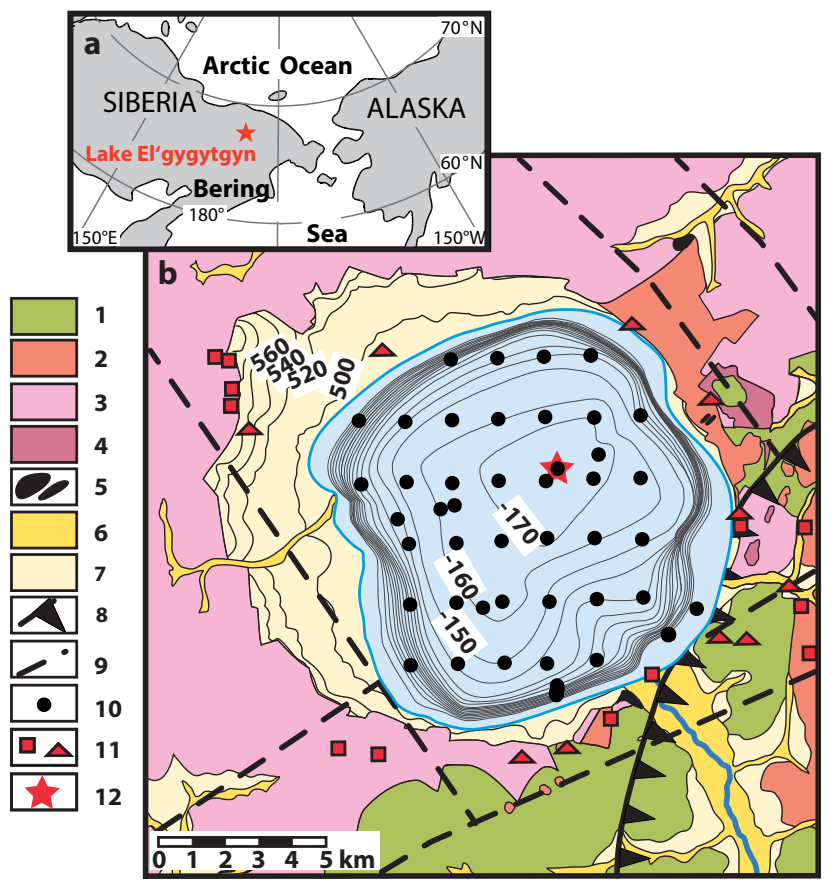

Fig. 1. (a) Map showing the location of Lake El'gygytgyn in the western Beringian Arctic, (b) geological map of the El'gygytgyn impact impact crater illustrating the major stratigraphic units (modified after Nowaczyk et al., 2002) and major fault systems (compiled after Belyi and Belaya, 1998; Belyi and Raikevich, 1994) in the lake catchment, bathymetric contour lines in the lake (modified after Belyi, 2001), and locations of lake floor and bedrock samples used in this study as well as of ICDP site 5011-1.; (1) Koekvun' Formation (basalt, andesite-basalt, tuff, tuff-breccia, sandstone, tuff-siltstone), (2) Ergyvaam Formation (ignimbrite, tuff), (3) Pykarvaam Formation (ignimbrite, tuff), (4) Voron'in Formation (ignimbrite, tuff), (5) dykes, stocks, and sills of subvolcanic rocks, (6) flood plain deposits, (7) terrace deposits, (8) boundary between the outer and inner OCVB zones, (9) major faults, (10) lake sediment surface samples, (11) bedrock samples (with squares referring to data from this study and triangles to data taken from Belyi and Belaya, 1998), (12) ICDP site 5011-1.

and Smirnov, 2007), resulting in widely time-continuous sedimentation. The lake is located in a region influenced by both Siberian and North Pacific oceanic air-masses (Barr and Clark, 2011; Yanase and Abe-Ouchi, 2007; Mock et al., 1998), making it very sensitive to regional atmospheric change. The high potential of Lake El'gygytgyn as a globally significant paleoclimate and environmental archive is confirmed by numerous studies on the lake sediments formed during the past three glacial/interglacial cycles (BrighamGrette et al., 2007b; Lozhkin et al., 2007; Melles et al., 2007; Minyuk et al., 2007; Nowaczyk et al., 2007; Swann et al., 2010; Asikainen et al., 2007).

Within the framework of the pre-site survey research, modern climatological and hydrological processes in the lake surrounding and in the water column were intensively inves- tigated (e.g. Cremer and Wagner, 2003; Cremer et al., 2005; Nolan and Brigham-Grette, 2007; Nolan et al., 2002; Fedorov et al., 2012), and a variety of modern to sub-recent sample sets were taken for study (Melles et al., 2005).

Here, we present the combined results of a multi-proxy and statistical approach to enhance the understanding of the modern sedimentation of Lake El'gygytgyn by analyzing a set of surface sediment and inlet streams samples, as well as hand samples from the surrounding bedrock. The major goal of this study is to provide information concerning the dominant sedimentation patterns in the lake controlled by climate-driven transport processes, bedrock geology, postdepositional processes, but possibly also influenced by tectonic activity. In combination with recent climatologic and hydrologic data (Nolan, 2012; Fedorov et al., 2012), these findings will enhance our understanding of fundamental inlake processes, and thus, form an important basis for the interpretation of the Lake El'gygytgyn paleo-record extending to $3.58 \mathrm{Ma}$.

\section{Study site}

Lake El'gygytgyn $\left(67^{\circ} 30^{\prime} \mathrm{N}, 172^{\circ} 05^{\prime} \mathrm{E}, 492 \mathrm{~m}\right.$ a.s.l.; Fig. 1) is located within the Anadyr Mountain Range in central Chukotka/ Far East Russian Arctic. Today, the roughly circular lake has a diameter of $\sim 12 \mathrm{~km}$ and a maximum water depth of $175 \mathrm{~m}$ (Nolan and Brigham-Grette, 2007; Melles et al., 2007), filling the deepest part of the $\sim 18-\mathrm{km}$ wide El'gygytgyn impact crater (Gurov et al., 2007). With a surface area of $\sim 110 \mathrm{~km}^{2}$, the lake is fed by 50 ephemeral streams draining a watershed area of $293 \mathrm{~km}^{2}$ defined by the crater rim (Nolan et al., 2002; Fig. 2a). The outlet stream, the Enmyvaam River at the south-eastern edge of the lake, flows into the Anadyr River, which eventually drains into the Bering Sea (Nolan and Brigham-Grette, 2007).

The climate in Chukotka is characterized by low mean winter and summer temperatures between $-32^{\circ} \mathrm{C}$ and $-36^{\circ} \mathrm{C}$ (January) and between $+4^{\circ}$ and $+8^{\circ} \mathrm{C}$ (July, August), respectively (Treshnikov, 1985), and a mean annual precipitation of $\sim 250 \mathrm{~mm}$ (Glotov and Zuev, 1995). In 2002, winter and summer temperature extremes of $-40^{\circ} \mathrm{C}$ and $+26{ }^{\circ} \mathrm{C}$, respectively, were recorded at Lake El'gygytgyn (Nolan and Brigham-Grette, 2007). Strong winds either from the north or south with a mean hourly wind speed of $5.6 \mathrm{~ms}^{-1}$ were punctuated by maximum values up to $21.0 \mathrm{~ms}^{-1}$ (Nolan and Brigham-Grette, 2007).

Lake El'gygytgyn is an oligotrophic to ultra-oligotrophic and cold-monomictic lake (Cremer and Wagner, 2003), with a yearly ice-cover lasting from mid-October until early to mid-July (Nolan et al., 2002). While thermal stratification of the water column is today established during the ice-covered season (Cremer et al., 2005), the lake becomes fully mixed by late summer after snowmelt and the initial ice break-up, triggered by the lateral movement of warmer shore-waters 

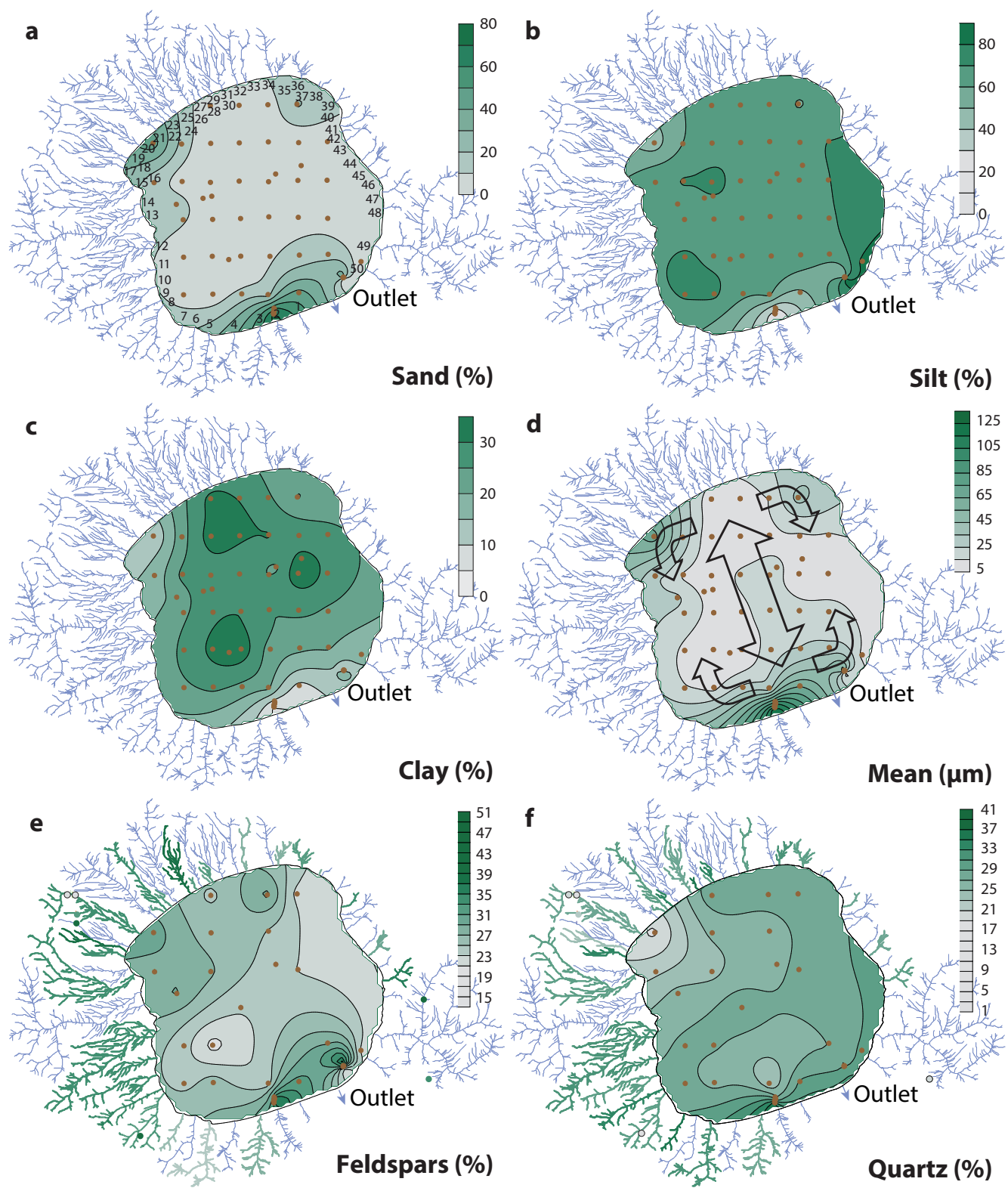

Fig. 2. Spatial distribution of volume percentages of (a) sand, (b) silt and (c) clay, (d) mean grain size, and proportions of (e) feldspars and (f) quartz in modern surface sediments (brown dots = sample location), inlet streams (coloured streams) and bedrock samples (coloured circles) of Lake El'gygytgyn. Numbers near the stream mouths in (a) refer to the creek numbering system of Nolan and Brigham-Grette (2007). Arrows in (d) indicate the near-surface circulation pattern, created by prevailing northern and southern wind directions (modified after Nolan and Brigham-Grette, 2007). Note that data of inlet stream and bedrock samples are only available for (e) and (f).

and enhanced by strong winds (Nolan and Brigham-Grette, 2007). The residence time of the lake water was calculated to be $\sim 100 \mathrm{yr}$ (Fedorov et al., 2012).

Geomorphological studies in the lake catchment have identified prominent lake terraces at $35-40 \mathrm{~m}, 9-11 \mathrm{~m}$ and 3-5 $\mathrm{m}$ above the modern lake level as remains of lake-level high-stands during the lake history (Glushkova and Smirnov, 2007; Schwamborn et al., 2008a, 2006). In addition, an an- cient terrace $10 \mathrm{~m}$ below the modern water level points to a significant lake-level lowering, most likely during MIS 2 (Juschus et al., 2011). Although the existence of higher terraces 60 and $80 \mathrm{~m}$ above the recent lake level has been suggested (Gurov et al., 2007; Nekrasov, 1963), their lacustrine origin has not yet been finally confirmed (Glushkova and Smirnov, 2005; Juschus et al., 2011). 
The El'gygytgyn impact crater was formed in Upper Cretaceous volcanic rocks of the Okhotsk-Chukchi Volcanic Belt (OCVB) (Gurov et al., 2007; Gurov and Gurova, 1979). The bedrock in the vicinity of the lake predominantly consists of ignimbrites, tuffs and andesite-basalts associated with the Pykarvaam, Voron'in, Koekvun' and Ergyvaam Formations (Belyi and Raikevich, 1994; Nowaczyk et al., 2002; Fig. 1b) dated to about 67-90 Ma (Kelley et al., 1999; Stone et al., 2009). The region of Lake El'gygytgyn is affected by continuous permafrost, presumably since the Late Pliocene (Glushkova and Smirnov, 2007). Erosion and detrital sediment transport of bedrock material into the lake basin are mainly triggered by permafrost related cryogenic weathering, as well as slope dynamics, and fluvial outwash in the lake surrounding (Schwamborn et al., 2008b, 2012; Fedorov et al., 2012). Thus, climate-driven variations in permafrost stability are believed to have a major influence on the lake sedimentation.

\section{Material and methods}

\subsection{Field work}

During a field campaign in summer 2003, a set of 55 surface sediment samples was collected from the floor of Lake El'gygytgyn (Fig. 1b). The samples were recovered from a floating platform using a gravity corer (UWITEC Corp., Austria) with plastic liners of $6 \mathrm{~cm}$ in diameter. Sample locations were determined according to a regular map grid, except for the shallowest parts of the lake, which were sampled along a transect at the southern shelf and at three sites along the southeastern shelf. This study is based on the uppermost $2 \mathrm{~cm}$ of the gravity cores, which represents roughly the past 150 years based on Holocene sedimentation rates (Fig. 3).

To investigate the influence of both fluvial sediment supply and bedrock geology on the modern sediments of Lake El'gygytgyn, an additional 30 sediment samples were taken from the major inlet streams entering the lake, and another 11 bedrock samples were collected from the lake catchment (Fig. 1b). The bedrock samples were supplemented by additional XRF data of bedrock samples taken from the literature (Belyi and Belaya, 1998).

\subsection{Analytical work}

Sediment samples from both the lake floor and inlet streams were freeze-dried in the lab and subsequently split into sample aliquots. Aliquots for geochemical and biogeochemical analyzes were ground to $<63 \mu \mathrm{m}$ and homogenized. Total nitrogen (TN) was measured with an elemental analyzer (vario EL III, elementar Corp.). The total organic carbon content (TOC) was measured using a METALYT CS $1000 \mathrm{~S}$ analyzer (ELTRA Corp.), after pretreating the sediment with $10 \% \mathrm{HCl}$ to remove carbonates.

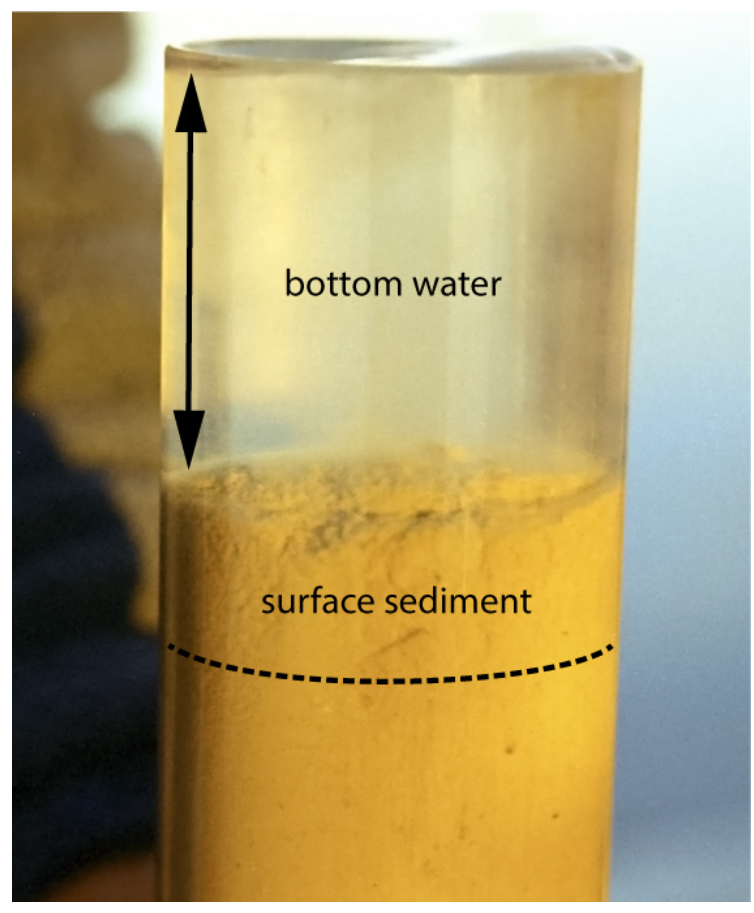

Fig. 3. Photograph of a gravity core taken near the northern shore of Lake El'gygytgyn from a water depth of $127.4 \mathrm{~m}$. Surface samples used in this study comprise the uppermost $2 \mathrm{~cm}$ of the sediments (above the dotted line) representing roughly the past $150 \mathrm{yr}$ based on Holocene sedimentation rates.

Major and trace elements were measured by ICP-OES (iCAP 6300 DUO, Thermo Scientific) after $\mathrm{HClO}_{4} / \mathrm{HF}$ total digestions. Acid digestion was performed in closed Teflon vessels (PDS-6) heated for $6 \mathrm{~h}$ at $180^{\circ} \mathrm{C}$ by treating $100 \mathrm{mg}$ sample with $3 \mathrm{~mL} \mathrm{HF}+1 \mathrm{~mL} \mathrm{HClO}_{4}$. After digestion, acids were evaporated using a heated metal block $\left(180^{\circ} \mathrm{C}\right)$ and were re-dissolved and evaporated three times with $3 \mathrm{~mL}$ halfconcentrated $\mathrm{HCl}$, followed by re-dissolution with $2 \mathrm{vol} \%$ $\mathrm{HNO}_{3}$ and dilution to $25 \mathrm{~mL}$. Precision $(1 \sigma)$ and accuracy were checked by parallel analysis of international and inhouse reference materials, leading to $\leq 2.8$ to $\leq 2.6 \%$ for major elements and $\leq 1.7$ to $\leq 12.1 \%$ for trace metals. Mercury was directly determined using $30-50 \mathrm{mg}$ of dry homogenized sediment using a DMA-80 Direct Mercury Analyzer (MLS instruments). The analysis is based on combustion of the sample and pre-concentration of $\mathrm{Hg}$ at a gold trap (amalgam), re-heating and determination of $\mathrm{Hg}$ gas by atomicabsorption spectrometry (AAS). The detection limit of the analysis is very low $\left(<1 \mu \mathrm{g} \mathrm{kg}^{-1}\right)$ and the reproducibility (precision) is $\sim 5 \%$ relative to the standard deviation from the average value.

The major and trace element composition of the bedrock samples was determined by wavelength-dispersive X-ray fluorescence (XRF) analysis using a sequential X-ray spectrometer (Phillips PW2400) calibrated with natural and synthetic 
standards. Prior to analysis, powdered samples were heated for four hours at $105^{\circ} \mathrm{C}$ before fusion with $\mathrm{Li}_{2} \mathrm{~B}_{4} \mathrm{O}_{7}$.

Bulk mineral contents of selected surface sediment $(n=$ $22)$, stream $(n=23)$ and bedrock samples $(n=7)$ were determined by X-ray diffraction (XRD). XRD analyses were run on pressed powder pellets using a Philips PW 1820 diffractometer with $\mathrm{CoK} \alpha$ radiation $(40 \mathrm{kV}, 40 \mathrm{~mA})$, automatic divergence slit (ADS), graphite monochromator, and automatic sample changer. Scanning was performed from $3^{\circ}$ to $100^{\circ}$ 2theta with a step size of $0.02^{\circ}$ 2theta and 1 seconds time per step. Mineral identifications were done by means of the Philips software $X^{\prime}$ Pert HighScore ${ }^{\mathrm{TM}}$ and sheet silicates were identified and quantified with the X-ray diffraction interpretation software MacDiff 4.25 (Petschick et al., 1996). Full quantification of the bulk mineral assemblage was carried out using the QUAX software package (Emmermann and Lauterjung, 1990) following the QUAX full pattern method (Vogt et al., 2002). The standard deviation for bulk mineral determination is $\pm 2 \%$ for quartz (Vogt, 1997) and $\pm 5-10 \%$ for feldspars and clay minerals (Vogt et al., 2002).

Grain-size analyses were performed on $1 \mathrm{~g}$ freeze-dried sediment. Prior to the measurement, samples were pretreated according to Francke et al. (2013) to remove organic matter $\left(30 \% \mathrm{H}_{2} \mathrm{O}_{2}, 50^{\circ} \mathrm{C}, 18 \mathrm{~h}\right)$, vivianite nodules $(0.5 \mathrm{M}$ $\mathrm{HNO}_{3}, 50^{\circ} \mathrm{C}, 5 \mathrm{~h}, 30 \mathrm{~min}$ shaking in between) and biogenic silica $\left(0.5 \mathrm{M} \mathrm{NaOH}\right.$ leaching, $90^{\circ} \mathrm{C}, 2 \times 30 \mathrm{~min}$. $)$. The results of the treatment steps were validated by biogeochemical analyses, Fourier Transform Infrared Spectroscopy (FTIRS), XRD, scanning electron microscopy (SEM) and optical microscopic investigations (Francke et al., 2013). Subsequently, the samples were mixed with $\mathrm{Na}_{4} \mathrm{P}_{2} \mathrm{O}_{7}$ solution $(0.05 \%$ w/v $)$ as a dispersant agent and finally measured by a Laser Particle Size Analyzer (DigiSizer 5200, Micromeritics Instrument Corp.). The laser-diffractometer uses a 1MB CCDsensor and calculates 160 grain-size classes between 0.1 and $1000 \mu \mathrm{m}$ with average values of three runs. One minute of ultrasonic treatment and flow rates of $10 \mathrm{~L} \mathrm{~min}^{-1}$ re-suspended the sediments prior to the analysis.

\subsection{Statistics and interpolation}

Calculations of grain-size parameters and statistics were performed using the program GRADISTAT (Blott and Pye, 2001). The statistical grain-size parameters were calculated according to the arithmetic method of moments.

To handle and simplify the element data of the surface sediments, and to visualize grain-size dependencies, both principal component analysis (PCA) and redundancy analysis (RDA) were carried out. Analyses were conducted using the Microsoft Excel add-in XLSTAT (Addinsoft SARL) with chemical element data as dependent response variables and various grain-size parameters (mean, mode, median, percentages of sand, mud, silt, clay, medium sand, fine sand, very fine sand, very coarse silt, coarse silt, medium silt, fine silt, very fine silt) as explanatory variables, respectively.

Interpolation and mapping of the surface sediment datasets were performed with the software Surfer 9 (Golden Software Inc.) using the Kriging method (Cressie, 1991; Oliver and Webster, 1990).

\section{Results}

\subsection{Grain-size distribution}

The surface sediments of Lake El'gygytgyn are silt dominated (Fig. 2b) with a mean grain-size ranging between 7.3 and $69.6 \mu \mathrm{m}$ (Fig. 2d). The spatial distribution of the mean grain-size shows fine-grained sediments in the northern, eastern and western central lake basin, whereas coarser material is found at the southern, northwestern and northeastern edges of the lake (Fig. 2d). Coarse-grained areas with high sand content ( $>63 \mu \mathrm{m}$ ) up to $73.8 \%$ are located in the northwestern and northeastern corners of the lake and along the southern shore (Fig. 2a). Highest silt contents $(2-63 \mu \mathrm{m})$ with maximum values up to $82.3 \%$ (Fig. $2 \mathrm{~b}$ ) are observed at the southeastern edge of the basin near the mouth of creeks 49 and 50 (creek numbers according to Nolan et al., 2002; Fig. 2a). The clay content varies between $8.4 \%$ at the southern shore and $33.6 \%$ in the central lake basin (Fig. 2c).

Surprisingly, the center of the lake exhibits a tongue of sediments with higher mean grain sizes around 15-25 $\mu \mathrm{m}$, extending from the southern shore towards the lake center (Fig. 2d). This feature is mainly due to a slight shift of the mean caused by an increase in very coarse silt ( $31-63 \mu \mathrm{m})$ of up to $17 \%$.

\subsection{Bulk mineralogy}

The bulk mineral composition of the surface sediments is dominated by a mixture of quartz, feldspars (plagioclase and K-feldspars), clay minerals and accessory minerals (Table 1). Although bedrock samples of the catchment contain fairly scattered amounts of quartz ranging from 2.9-27.7\%, the surface sediment and inlet stream samples show a rather heterogeneous quartz distribution with a clear enrichment (up to $34.3 \%$ ) at the southern and southeastern shore (Fig. 2f). Conversely, the northwestern shore is characterized by lowest quartz content.

Feldspars also exhibit high concentrations in the surface sediments at the southern and northeastern shores (max. $42.5 \%$ ) but differ from quartz due to the high concentration also found at the northwestern shore and a pronounced low in the central and eastern part of the lake (max. 22.8\%; Fig. 2e). These values fit within the concentration range of the inlet stream samples (25.4-40.0\%) and of the bedrock material (15.1-51.4\%; Fig. 2e). In the latter, feldspars occur as phenocrysts of orthoclase $\left(\mathrm{KAlSi}_{3} \mathrm{O}_{8}\right)$ and plagioclase, mainly of oligoclase and 
Table 1. Averaged bulk mineralogy composition of surface sediments, inlet stream and bedrock samples of Lake El'gygytgyn. For creek numbering see Fig. 2a.

\begin{tabular}{|c|c|c|c|c|c|c|c|c|c|c|c|c|c|c|c|c|c|c|c|c|c|c|}
\hline & 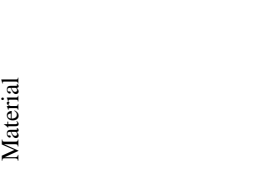 & $n$ & $\begin{array}{l}\mathrm{N} \\
\text { Z } \\
\text { E }\end{array}$ & 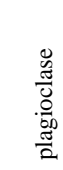 & $\begin{array}{l}\vec{z} \\
\frac{a}{0} \\
\frac{0}{0} \\
\frac{1}{1}\end{array}$ & $\frac{\stackrel{0}{0}}{\tilde{J}}$ & 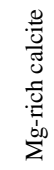 & 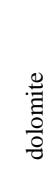 & 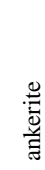 & $\frac{\mathscr{\theta}}{\frac{0}{0}}$ & 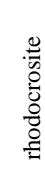 & 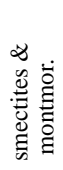 & 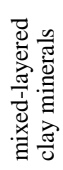 & 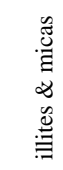 & 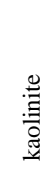 & $\frac{0}{\frac{0}{0}}$ & 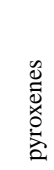 & 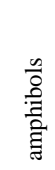 & $\frac{\mathscr{O}}{\stackrel{\mathscr{O}}{0}}$ & & 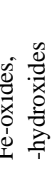 & : \\
\hline \multirow{4}{*}{ 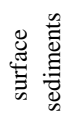 } & nortl & 5 & 23.9 & 21.4 & 8.4 & 2.0 & 2.8 & 1.4 & 0.2 & 0.1 & 0.5 & 6.5 & 2.4 & 9.0 & 1.3 & 2.5 & 4.3 & 0.4 & 1.9 & 0.8 & 3.6 & 0.6 \\
\hline & southern shelf & 15 & 29.3 & 27.4 & 6.9 & 1.2 & 2.2 & 1.3 & 0.2 & 0.1 & 0.8 & 4.2 & 2.6 & 11.0 & 1.3 & 2.2 & 3.8 & 0.3 & 2.6 & 0.6 & 1.8 & 0.3 \\
\hline & central basin & 10 & 26.1 & 20.8 & 5.5 & 2.0 & 2.5 & 1.3 & 0.2 & 0.1 & 0.6 & 7.1 & 3.5 & 10.2 & 2.0 & 3.5 & 4.3 & 0.4 & 4.5 & 0.7 & 4.4 & 1.1 \\
\hline & southwestern shelf & 6 & 28.0 & 24.2 & 6.0 & 1.0 & 2.1 & 1.0 & 0.2 & 0.1 & 0.7 & 5.7 & 3.0 & 12.8 & 3.0 & 3.8 & 3.7 & 0.1 & 4.7 & 0.6 & 1.3 & 0.6 \\
\hline \multirow{3}{*}{ 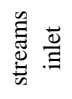 } & S \& & 11 & 30.3 & 6.7 & 7.0 & 1.8 & 2.6 & 1.6 & 0.4 & 0.1 & 0.6 & 1.9 & 3.0 & 10.6 & 0.6 & 1.7 & 3.7 & 0.5 & 1.7 & 0.7 & 3.6 & 0.4 \\
\hline & $\mathrm{N}$ (creeks 19-37) & 12 & 28.9 & 26.0 & 7.2 & 2.2 & 2.5 & 2.1 & 0.4 & 0.1 & 0.7 & 2.1 & 2.0 & 6.3 & 0.5 & 1.4 & 4.2 & 0.3 & 5.7 & 0.9 & 5.3 & 0.5 \\
\hline & E \& SE (creeks 39-50) & 3 & 26.2 & 26.7 & 8.9 & 2.1 & 1.9 & 1.6 & 0.3 & 0.1 & 0.6 & 4.7 & 2.9 & 6.0 & 1.2 & 2.1 & 4.2 & 0.3 & 3.9 & 1.2 & 4.0 & 0.7 \\
\hline \multirow{3}{*}{ 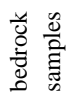 } & Pykar & 5 & 18.5 & 20.1 & 5.2 & 1.0 & 5.2 & 1.2 & 0.0 & & 0.1 & 2.0 & 1.9 & 21.7 & 0.6 & 1.1 & 5.7 & & 2.1 & 0.7 & 5.1 & 0.5 \\
\hline & Koekvuum Form. & 1 & 2.9 & 41.9 & 8.7 & 5.8 & 1.2 & 4.2 & 0.1 & 0.3 & 0.4 & 1.7 & 2.7 & 3.4 & 0.3 & 2.5 & 0.3 & 0.1 & 1.9 & 5.2 & 6.6 & 1.1 \\
\hline & Ergyvaam Form. & 1 & 26.9 & 26.0 & 10.4 & 1.0 & 2.6 & 2.0 & 0.0 & 0.2 & 0.1 & 1.5 & 1.9 & 5.4 & 4.1 & 9.9 & 4.5 & 0.4 & 8.6 & 0.7 & 0.3 & 0.5 \\
\hline
\end{tabular}

andesine $\left((\mathrm{Na}, \mathrm{Ca})\left[\mathrm{Al}(\mathrm{Si}, \mathrm{Al}) \mathrm{Si}_{2} \mathrm{O}_{8}\right]\right)$, in both the acid and andesitic volcanic rocks (Gurov et al., 2005; Belyi, 2010).

The clay mineral assemblage is composed of illite, smectite, chlorite, mixed layer clay minerals, and to a minor amount, kaolinite (Table 1), which concurs with earlier downcore clay mineral analyses from Lake El'gygytgyn (Asikainen et al., 2007). Furthermore, zeolites (up to $4.7 \%$ ), pyroxenes (up to $4.3 \%$ ) and Fe-oxides and -hydroxides (up to $4.4 \%$ ) occur in considerable amounts (Table 1), whereas carbonate phases, such as calcite $\left(\mathrm{CaCO}_{3}\right), \mathrm{Mg}$-rich calcite, siderite $\left(\mathrm{FeCO}_{3}\right)$ and rhodochrosite $\left(\mathrm{MnCO}_{3}\right)$, play only a minor role in surface sediments with contents $<3 \%$ (Table 1). The accessory mineral assemblage resembles the composition of the inlet streams and bedrock samples.

\subsection{Element composition}

Based on the PCA results of the elemental concentrations in Lake El'gygytgyn surface sediments, three dominant element clusters can be defined. Group I, with high loadings on principle component (PC) 2 and low loadings on PC 1, includes $\mathrm{Al}_{2} \mathrm{O}_{3}, \mathrm{Na}_{2} \mathrm{O}, \mathrm{CaO}, \mathrm{K}_{2} \mathrm{O}, \mathrm{Ba}$ and $\mathrm{Sr}$ (Fig. 4a). As illustrated in $\mathrm{K}_{2} \mathrm{O}$ concentrations as high as $6.65 \%$ (Fig. 5a), these elements are typically enriched close to the southern and northern shores but are rather depleted in the central lake basin. Lower $\mathrm{K}_{2} \mathrm{O}$ concentrations are also indicated at the southeastern shore, but are represented only by a single value (Fig. 5a). Bedrock samples show a clear differentiation of group I elements in the different formations, with low $\mathrm{K}_{2} \mathrm{O}$ concentrations of $1.2-2.2 \%$ in the basaltic to andesitic rocks of the Koekvun' Formation, but distinctly higher values in the rhyolithic source rocks of the Pykarvaam (3.3-4.4\%) and Ergyvaam Formations (4.7\%; Fig. 5a). In contrast, the inlet stream samples show a rather homogeneous distribution of group I elements, with high $\mathrm{K}_{2} \mathrm{O}$ concentrations ranging between 4.5 and $8.5 \%$.
Another cluster in the PCA results comprises the elements of group II, including $\mathrm{Cr}, \mathrm{Cu}, \mathrm{Zr}, \mathrm{TiO}_{2}, \mathrm{Zn}, \mathrm{V}, \mathrm{Ni}, \mathrm{Fe}_{2} \mathrm{O}_{3}, \mathrm{Co}$ and $\mathrm{Cd}$, showing high loadings of PC 1 and only low negative loadings of PC 2 (Fig. 4a). As shown for instance in the distribution plot of $\mathrm{Cr}$ (Fig. 5b), these elements are highly enriched in the southeastern part of Lake El'gygytgyn (up to $70.3 \mathrm{mg} \mathrm{kg}^{-1} \mathrm{Cr}$ ) and along the eastern shore, whereas the other parts of the basin show relatively low concentrations $\left(6.3-30.5 \mathrm{mg} \mathrm{kg}^{-1} \mathrm{Cr}\right)$. A similar heterogeneity in the distribution of group II elements is also valid for the bedrock and stream samples, with rather low values in most of the lake catchment but a clear enrichment in bedrock samples from the southeastern crater rim (up to $104 \mathrm{mg} \mathrm{kg}^{-1} \mathrm{Cr}$ ) and sediments from streams 48 to $50\left(30.1-154.0 \mathrm{mg} \mathrm{kg}^{-1} \mathrm{Cr}\right.$; Fig. 5b).

A third group of elements, characterized by medium negative loadings of $\mathrm{PC} 1$ and high negative loadings of $\mathrm{PC} 2$ in the PCA, contain typical heavy metals, such as $\mathrm{Pb}, \mathrm{Mo}, \mathrm{MnO}$, As, but also $\mathrm{P}_{2} \mathrm{O}_{5}, \mathrm{SO}_{2}$ and $\mathrm{Hg}$ (Fig. 4a). With the exception of arsenic, group III elements are typically elevated in the deepest part of the lake basin (e.g. MnO: 0.06-0.11\%), and are depleted in sediments along the coarse-grained northern and southern shores (e.g. MnO: 0.03-0.05\%; Fig. 5c). This spatial distribution significantly differs from bedrock and creek samples, showing a clear group III enrichment in the basaltic to andesitic rocks (MnO: $0.15-0.16 \%$ ) and stream samples (MnO: 0.07-0.09\%) of the southeastern crater rim.

Mercury is heterogeneously distributed in the recent sediments of Lake El'gygytgyn, in contrast to other group III elements. For major parts of the lake basin, $\mathrm{Hg}$ concentrations in the surface elements do not exceed $150 \mu \mathrm{g} \mathrm{kg}^{-1}$ (Fig. 5d). In the northern central lake basin, in contrast, mercury exhibits a pronounced local maximum, with two sample locations yielding 4-5 times higher $\mathrm{Hg}$ contents (476 and $576 \mu \mathrm{g} \mathrm{kg}^{-1}$ ) compared to all other lake sediment samples. Sediments from creeks 46 and 50 in the southeastern corner 

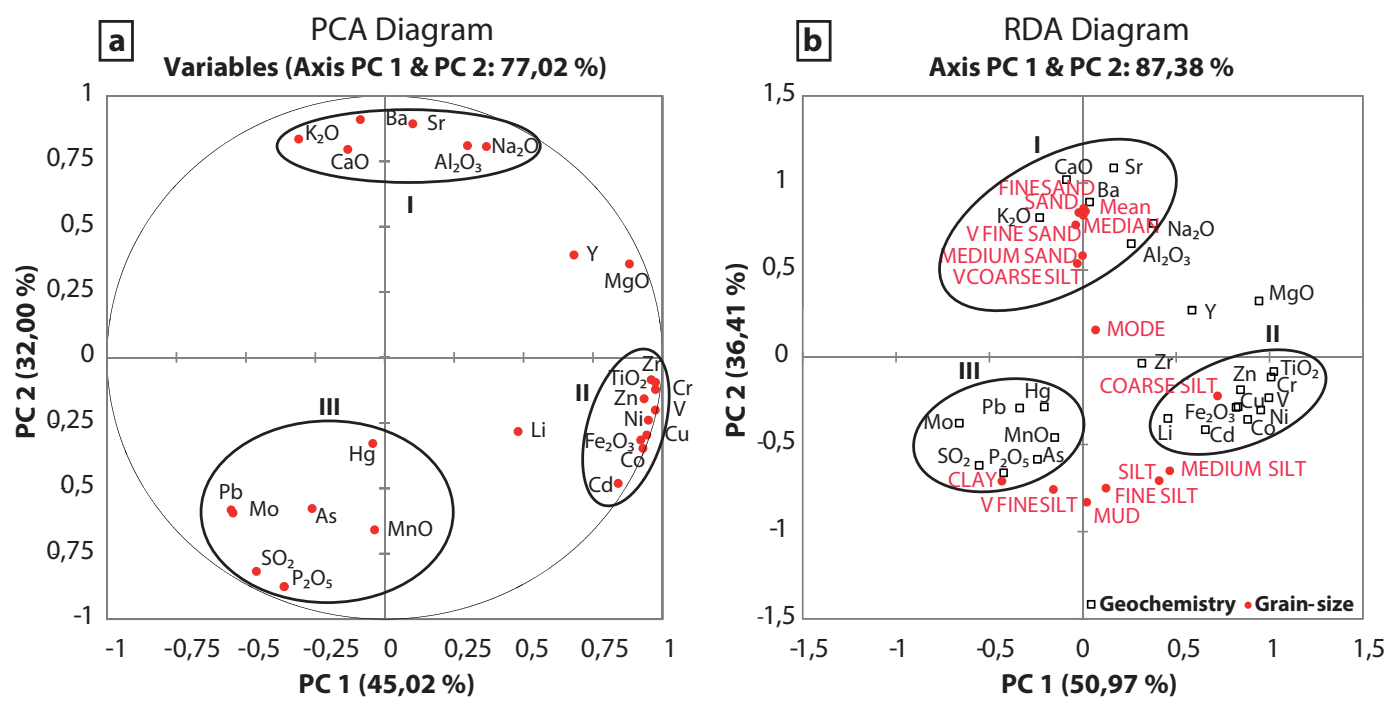

Fig. 4. Result of the (a) principal component analysis (PCA) of the inorganic geochemistry and (b) redundancy analysis (RDA) of the inorganic geochemistry and grain-size parameters (explanatory variables) in surface sediments of Lake El'gygytgyn.

of the basin yield $\mathrm{Hg}$ concentrations ranging between 182 $1142 \mu \mathrm{g} \mathrm{kg}^{-1}$, whereas mercury does not exceed $110 \mu \mathrm{g} \mathrm{kg}^{-1}$ at most of the other inlet streams (Fig. 5d).

\section{Discussion}

Lake El'gygytgyn surface sediments show a variety of distribution patterns based on grain-size parameters, element concentrations, bulk mineralogy, and organic parameters, which are controlled by transport processes, bedrock geology, early diagenetic processes and potential tectonic activity. Thus, these data have a direct impact on the interpretation of the paleoclimate record derived from sediment cores of Lake El'gygytgyn.

\subsection{Sediment transport mechanisms within the water body}

The grain-size distribution in the surface sediments of Lake El'gygytgyn and especially the mean grain size traces the general path of a two-cell wind induced current system in Lake El'gygytgyn (Fig. 2d), which appears to be triggered by strong winds from the north or south, as postulated by Nolan and Brigham-Grette (2007). Similar wind-driven two-cell current circulation systems are common features in Arctic lakes (e.g. Côté and Burn, 2002), often resulting in oriented lake bodies with an elliptical shape perpendicular to the main wind direction. Consistent with the occurrence of coarsegrained sediments found in the northwestern and northeastern corners of the lake and along the southern shore (Fig. 2a and d), maximum littoral drift at the edges of the lake, coincident with the highest erosional forces obviously prevents the deposition of fine-grained material (Nolan and BrighamGrette, 2007).

The coarse-grained tongue extending from the southern shore towards the lake center cannot be of fluvial origin because large inlet streams as possible source do not exist along the southern shore. Furthermore, due to the low sand content within the area of the tongue (Fig. 2a) sediment transport from the southern, very sandy shelf by ice-rafting is also unlikely. Turbidity currents, whose deposits are typically characterized by graded bedding of the sediments with a coarse base and a fine silt/clay cap, are rather abundant in older sediments of Lake El'gygytgyn but have not been observed for the last 3200 uncal. ${ }^{14} \mathrm{C}$ years (Juschus et al., 2009; Sauerbrey et al., 2013). The lack of the typical structure in the modern sediments along the coarse tongue also rules out an origin from turbidity currents. Thus, the coarser sediment tongue is most likely the result of wave-induced re-suspension processes (Bloesch, 1995) with an erosion of fine-grained material from the shallow southern shelf (water depth $<10 \mathrm{~m}$ ) during heavy storms with northerly wind directions and a subsequent northward transport by sub-surface currents. This suggestion is supported by the very coarse grain-size characteristically found on the southern shelf (Fig. 2a and d). The occurrence of such re-suspension processes was observed during a heavy storm from the north in August 2003. Wind velocities up to $16.8 \mathrm{~ms}^{-1}$ (Nolan, personal communication, 2012) and wave heights up to $1 \mathrm{~m}$ created a distinct northward reaching suspension cloud of $\sim 1 \mathrm{~km}$ in length in front of the Enmyvaam river (Fig. 6), accompanied by a nearly shut off of the outlet by coarse sediment drift. The visible suspension cloud ended just at the shelf edge, implying a further transport and dispersion of the material into the deeper lake basin presumably via vertical lake currents or 

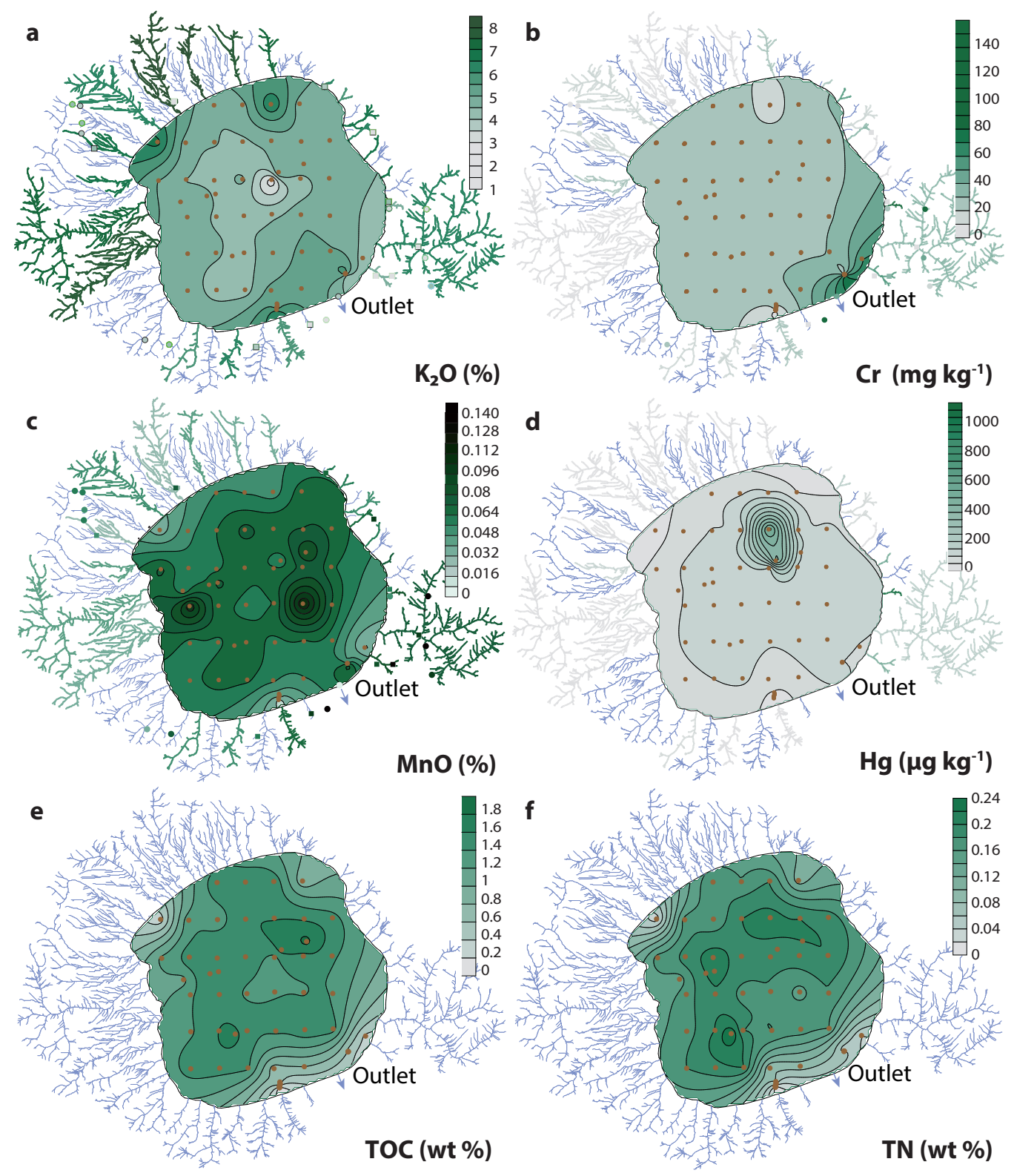

Fig. 5. Spatial distribution of concentrations of (a) $\mathrm{K}_{2} \mathrm{O}[\% \mathrm{wt} / \mathrm{wt}]$, (b) $\mathrm{Cr}\left[\mathrm{mg} \mathrm{kg}^{-1}\right]$, (c) $\mathrm{MnO}[\% \mathrm{wt} / \mathrm{wt}],(\mathbf{d}) \mathrm{Hg}^{2}\left[\mu \mathrm{gg}{ }^{-1}\right]$, (e) $\mathrm{TOC}[\%$ $\mathrm{wt} / \mathrm{wt}$, and (f) $\mathrm{TN}[\% \mathrm{wt} / \mathrm{wt}]$ in surface sediments (brown dots = sample location), inlet streams (coloured streams) and bedrock samples (coloured circles = this study; colored squares = taken from Belyi et al., 1998) of Lake El'gygytgyn. Note that no inlet stream and bedrock sample data are available for (e) and (f).

hyperpycnal near bottom flows as described for Lake Michigan (Hawley and Lee, 1999) or Lake Malawi (Halfman and Scholz, 1993). Between 2001 and 2005, similar heavy storms with wind speeds exceeding $10 \mathrm{~ms}^{-1}$ and a duration of more than four hours were recorded at Lake El'gygytgyn between 9 (2001, 2004) and 26 (2002) times during the ice-free season (mid- July-mid-October; Nolan et al., 2002). The formation of a major suspension fan is likely amplified by the slightly triangular morphology of the southern shore line (Fig. 1b), focusing the wave activity at the southeastern edge just in front of the Enmyvaam outlet. Furthermore, similarities in the spatial pattern of the coarser-grained sediment tongue and a NE-SW oriented ridge structure indicated in the bathymetry (Fig. 1b) may imply a higher sedimentation rates along the suspension fan. 


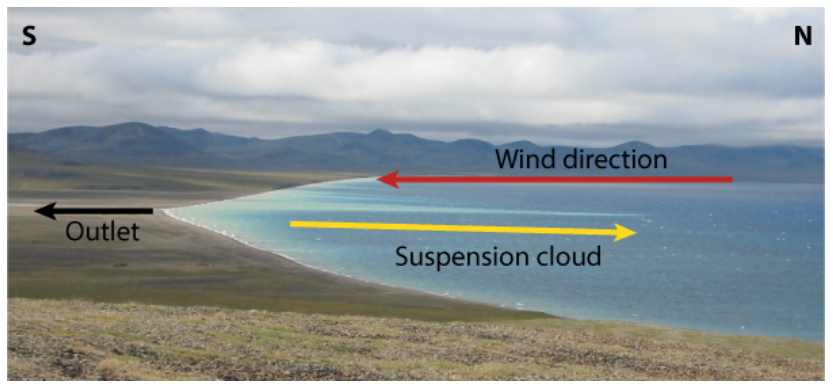

Fig. 6. Suspension cloud at the southern shelf of Lake El'gygytgyn, observed during a heavy storm with northerly winds in August 2003. View from the southeastern shore, also showing the Enmyvaam outlet stream exiting the lake to the left (distance ca. $1.5 \mathrm{~km})$.

The bulk mineralogy clearly follows the general grain-size distribution with quartz showing some similarity with the pattern of silt content (Fig. 2b and e), and feldspar exhibiting a distinct similarity with the pattern of the sand content (Figs. 2a and f). The obvious enrichments of quartz in the silt and feldspar in the coarse fraction of the surface sediment can be directly traced back to cryogenic weathering processes within the active layer of the permafrost in the lake surrounding, which promote this grain-size dependent fractionation and accumulation (Konishchev, 1982; Schwamborn et al., 2008b).

The general patterns in mineralogy are also mirrored in the elemental composition, with group I elements exhibiting a distinct similarity to the distribution pattern of feldspars. Thus, group I elements can most likely be linked to the amount of plagioclase and K-feldspars (Fig. 2e) originating from the surrounding acidic volcanic rocks. The dominance of acidic volcanic rocks is also indicated by the relatively homogeneous distribution of group I elements in the sediments of the inlet streams and the source rocks surrounding the lake. Since carbonate rocks are very rare in the catchment of Lake El'gygytgyn, mostly occurring as vein fillings in the suevite below the lake sediments (Melles et al., 2011), the main sources for strontium can be attributed to Na-Ca-feldspars, replacing sodium or calcium (Cherniak and Watson, 1994), and to K-feldspars, with strontium and barium known to substitute potassium (El Bouseily and El Sokkary, 1975).

The apparent $\mathrm{K}_{2} \mathrm{O}$ increase in the inlets and at the shelves of the northern and southern shore with respect to the respective source rocks implies an enrichment of potassium during cryogenic weathering and/or transport processes. This generally contradicts a higher grade of chemical weathering of the inlet stream deposits and surface sediments usually causing a depletion especially of $\mathrm{Na}$, but also $\mathrm{K}$ and $\mathrm{Ca}$ (Nesbitt and Young, 1984). Furthermore, the RDA results of the element concentrations with grain-size parameters as explanatory variables show a clear correlation of the group I ele- ments with the sand fraction (Fig. 4b). Consequently, elements of group I (e.g. K, Na, or Sr) might be used in sediment cores of Lake El'gygytgyn as indicators for coarser grain sizes (e.g. Wennrich et al., 2013).

\subsection{Indications for sediment sources}

The distinct clustering of group II elements in the east and southeast of the lake in combination with high concentrations of group II elements in the bedrock and inlet streams of the southeastern crater rim (Fig. 5b) suggest a bedrock source in the southeastern lake catchment. Especially $\mathrm{Cr}, \mathrm{Ni}$, $\mathrm{Cu}$ and $\mathrm{Co}$, but also $\mathrm{Fe}_{2} \mathrm{O}_{3}$, were reported to have maximum values in the basaltic rocks (basalts, andesite-basalts) of the Koekvun' Formation (Belyi and Belaya, 1998) that pervasively outcrops along the southeastern section of the crater (Nowaczyk et al., 2002).

Simultaneously, the southeastern edge of the lake basin exhibits a pronounced silt maximum (Fig. 2b) that most likely can be traced back to the high flux of fluvial suspension from creek 49 (informally called "Lagerny Creek") as major inlet of Lake El'gygytgyn. During snow melt, Lagerny Creek produces the highest water and sediment discharge of all inlet streams in the range of $6.1 \mathrm{~m}^{3} \mathrm{~s}^{-1}$ and $24.0 \mathrm{gs}^{-1}$, respectively (Fedorov et al., 2012).

A correspondence of group II elements and coarse silt $(16-31 \mu \mathrm{m})$ and, to some degree, the medium silt $(7-16 \mu \mathrm{m})$ and total silt fraction is not only supported by similarities in the spatial distribution patterns but also by the results of the RDA (Fig. 4b). Consequently, fluvial input of weathering products from the basaltic bedrock material via Lagerny Creek to the lake can be assumed as major source of group II elements. Nevertheless, group II elements exhibit a much more pronounced concentration gradient between the southeastern corner and the remaining lake basin compared to the silt content. This discrepancy most likely results from a very local source of group II elements, whereas the silt signal mirrors the general high input of silt-sized weathering products from the catchment into the lake that is further increased in the southeast by the high fluvial sediment input of Lagerny Creek.

The prevailing northward dispersion of this fluvial material along western lake shore (Figs. $2 \mathrm{~b}$ and $5 \mathrm{~b}$ ) implies an anti-clockwise circulation pattern at the western lake shore, and thus, suggests northerly winds may be slightly dominant during the ice-free period as drivers of the current circulation system. But due to the poor sample resolution in this region this pattern may also be the result of interpolation artifacts.

According to down-core investigations on ICDP Site 5011-1 (Fig. 1) and pilot core PG1351 in the central part of Lake El'gygytgyn, $\mathrm{Ti}, \mathrm{Fe}_{2} \mathrm{O}_{3}$, but also $\mathrm{Cr}$ and $\mathrm{Ni}$ typically are enriched during cold stages (Minyuk et al., 2007, 2011, 2013; Wennrich et al., 2013). Such sediments are usually characterized by low coarse silt to fine sand but higher clay and fine silt contents (Francke et al., 2013). This discrepancy implies a 
fundamental change in the weathering and/or sedimentation settings in Lake El'gygytgyn under a perennial ice cover during glacial periods.

\subsection{Indicators of post-depositional processes}

The RDA results (Fig. 4b) as well as similarities in the distribution patterns of heavy metals, e.g. $\mathrm{MnO}$, with those of clay, TOC and TN (Figs. 2c, 5c, e and f) strongly indicate group III elements in Lake El'gygytgyn surface sediments to follow the organic matter enriched fine fraction. The first suggests that group III elements are mainly bound to organic matter. Phosphorous and sulfur are typical components of lacustrine organic matter (Wetzel, 2001). Molybdenum as a catalyst for nitrogen fixation in living plants is generally accumulated in plant material (Bortels, 1930), but can also be fixed to the organic matter by early diagenetic processes (Robinson et al., 1993). But due to the high accordance of group III to clay, an incorporation of the heavy metals into crystal lattices of clay minerals (Lin and Puls, 2000; Tessier, 1992) has to be considered.

On the other hand, enhanced concentrations of heavy metals $(\mathrm{Pb}, \mathrm{As}, \mathrm{Mo})$, but also $\mathrm{P}_{2} \mathrm{O}_{5}$, in the central basin of a fully-mixed Lake El'gygtygyn (Cremer et al., 2005) might partly be linked to the enhanced occurrence of Fe-oxides and -hydroxides (Table 1). In recent sediments from Lake Baikal and the San Francisco Bay, iron and manganese oxides have been shown to be a significant sink for $\mathrm{P}, \mathrm{Mo}, \mathrm{Pb}, \mathrm{As}$ and other heavy metals by adsorption and co-precipitation (Lion et al., 1982; Müller et al., 2002).

Nevertheless, the occurrence of Fe-oxides and -hydroxides highlight the iron mineralogy at the sediment/water interface to clearly differ from those of Lake El'gygytgyn down-core sediments deposited during glacial periods, where higher $\mathrm{Fe}$ concentrations are linked to the diagenetic formation of vivianite $\left((\mathrm{Fe})_{3}\left(\mathrm{PO}_{4}\right)_{2} \cdot 8 \mathrm{H}_{2} \mathrm{O}\right)$ under reducing pore-water conditions (Minyuk et al., 2007, 2013), with manganese incorporated as an impurity into the vivianite structure (Fagel et al., 2005).

\subsection{Indicators of tectonic activity}

In major parts of the Lake El'gygytgyn basin, mercury behaves like other group III elements and is positively correlated with the TOC content $\left(r^{2}=0.61\right.$; Fig. 7). A similar coincidence of $\mathrm{Hg}$ and TOC was also observed in surficial sediments from Lake Baikal, with mercury as $\mathrm{Hg}^{0}$ mainly absorbed onto organic matter (Gelety et al., 2005, 2007). This TOC-Hg analogy generally supports a scavenging of mercury by algae and/or suspended algal material as mentioned by Outridge et al. (2007) for lakes in the Canadian High Arctic.

An atmospheric source of mercury has been described for many remote lakes (e.g. Lorey and Driscoll, 1999; Cannon et al., 2003; Bindler et al., 2001) and might also contribute

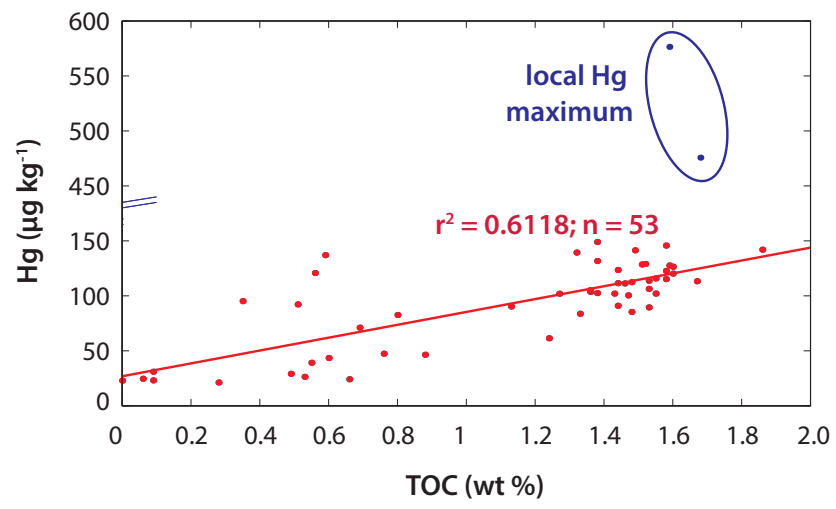

Fig. 7. Regression diagram of TOC [\% wt/wt] vs. $\mathrm{Hg}\left[\mu \mathrm{g} \mathrm{kg}^{-1}\right]$ for surface sediment samples of Lake El'gygytgyn $(n=55)$. Linear regression line and coefficient of determination were calculated excluding the values of the local $\mathrm{Hg}$ maximum $\left(>450 \mu \mathrm{g} \mathrm{kg}^{-1}\right)$.

to the $\mathrm{Hg}$ budget of Lake El'gygytgyn. But the heterogeneous distribution of $\mathrm{Hg}$ in both the surface sediments and the tributaries with a very pronounced maximum in one region of the lake floor implies a local $\mathrm{Hg}$ source. The most likely source of the elevated mercury contents are volcanic formations especially of the outer zone of the OCVB outcropping around the lake, which are known not only for its gold and silver resources, but also for rich mercury ore deposits (Sidorov et al., 2011). Interestingly, the peak concentrations in the inlet streams of the southeastern catchment fit the result of a gas mercury survey in the lake catchment in 2003 yielding elevated $\mathrm{Hg}$ values in the soil air just in this region of the El'gygytgyn crater (Fedorov and Kupolov, 2005). These were initially interpreted as tracers of tectonic activity along a NW-SE striking major boundary within the OCVB and a fault system associated with the Malyi-Chaun graben zone along the southern shore. Similar fault-related mercury anomalies in soils have also been reported from the Baikal Rift Zone (Koval et al., 2006, 1999), and can presumably be traced back to tectonically-driven mercury mobilization as described for $\mathrm{Hg}$ deposits in Spain (e.g. Jébrak and Hernandez, 1995).

Although recent seismic activity is reportedly low for the El'gygytgyn region (Fujita et al., 2002), minor faults mapped within the lake sediment stratigraphy during seismic surveys (Niessen et al., 2007) indicate ongoing neotectonic activity. Such fault re-activation explains well the elevated $\mathrm{Hg}$ values in the inlet stream sediments. As no obvious transport process exists to explain the $\mathrm{Hg}$ maximum at two sites in the lake surface sediments, a tectonic origin of the mercury anomaly in the lake center cannot be excluded, even though the seismic surveys did not yield any active faults in the respective lake area. Thus, further research is necessary to reveal the mercury sources and its cycle in Lake El'gygytgyn and to validate the theory of tectonically triggered $\mathrm{Hg}$ mobilization. Nevertheless, detailed $\mathrm{Hg}$ downcore analyses of the 
3.6 Ma record from the lake may have the potential to get new insights into the seismic history of this region, and/or the mechanisms that trigger mass movements.

\section{Conclusions}

A multi-proxy approach combining sedimentological, geochemical and mineralogical analyses with statistical methods was performed on a set of 55 surface sediment samples from Lake El'gygytgyn, NE Russia. The results of this study provide a detailed understanding of the major physical and chemical processes controlling modern sedimentation in this remote Arctic crater lake.

1. The spatial distribution of mean grain-size, sand and feldspar contents, and the concentration of group I elements ( $\mathrm{Ba}, \mathrm{Sr}, \mathrm{Al}_{2} \mathrm{O}_{3}, \mathrm{Na}_{2} \mathrm{O}, \mathrm{CaO}$, and $\mathrm{K}_{2} \mathrm{O}$ ) confirms the existence of a wind-induced two-cell current system triggering the surface-water circulation in the lake. Furthermore, mean grain-size strongly suggests transport of relatively coarse sediment from the southern shore towards the lake center as a result of the re-suspension of clay and silt-sized material during heavy storm events. High correlation of group I elements with the coarse fraction suggests that elements like sodium, calcium or strontium can be used as grain-size indicators in downcore samples of Lake El'gygytgyn.

2. Mafic rock related elements, such as $\mathrm{Cr}, \mathrm{Cu}, \mathrm{Zn}, \mathrm{V}, \mathrm{Ni}$, and $\mathrm{Co}$, can be directly linked to basaltic volcanic rocks in the southeastern quadrant of the crater, implying a significant source-rock effect controlling the spatial distribution of these elements. The largely northward dispersion of the silt-sized basaltic weathering products confirms the suggestion of a two-cell surface current system with a dominating anti-clock wise circulation at the southeastern shore.

3. The distribution of $\mathrm{MnO}$ and heavy elements like $\mathrm{Pb}$, Mo, As and $\mathrm{Hg}$, but also $\mathrm{P}_{2} \mathrm{O}_{5}$ and $\mathrm{SO}_{2}$, correlates with the organic matter and clay contents, which are generally enriched in the deepest parts of the lake basin. This correlation might be indicative of the sorption or co-precipitation of these elements with $\mathrm{Fe}$ and $\mathrm{Mn}$ hydroxides and oxides, and an additional fixation to organic matter or clay minerals in the oxic surface sediment layer.

4. Ongoing tectonic activity along a NW-SE striking fault zone in the lake catchment is indicated by variable mercury concentrations in the inlet stream deposits, being distinctly elevated in the southeastern corner of the lake catchment. A local Hg maximum in the lake center is not yet understood, but might point to ongoing neotectonic activity within the lake area as well.
These results are of essential importance for deciphering the climatic and environmental history of the area since 3.6 Ma from the composition of the sediments drilled on ICDP Site 5011-1 within the scope of the international El'gygytgyn Drilling Project.

Acknowledgements. We thank Nicole Mantke (University of Cologne), K. Bienert and Sylvia Dorn (University Leipzig) and numerous students for her technical assistance in the laboratory, and Rita Fröhlking (AWI Bremerhaven) for performing the XRD analyses. Furthermore, we would like to thank our funding agencies, namely the International Continental Scientific Drilling Program (IPDP), German Federal Ministry of Education and Research (BMBF; grant 03G0642), US National Science Foundation (grants OPP 007122, 96-15768, and 0002643), Russian Academy of Sciences, Austrian Federal Ministry of Science and Research and all the participants of the International "El'gygytgyn Drilling Project" for support and collaborations. Financial support of the pre-site survey was provided by the German Federal Ministry for Education and Research (BMBF), grant no. 03G0586A, and the US National Science Foundation (NSF), OPP Award \#96-15768, Atmospheric Sciences Award 99-05813, and OPP Award \#00-02643, and the Russian Fund of Basic Research, and CRDF. Finally we appreciate the comments and suggestions of Denis-Didier Rousseau, Pierre Francus and an anonymous reviewer who helped to improve the manuscript.

Edited by: D.-D. Rousseau

\section{References}

Allen, J. R. M., Brandt, U., Brauer, A., Hubberten, H.-W., Huntley, B., Keller, J., Kraml, M., Mackensen, A., Mingram, J., Negendank, J. F. W., Nowaczyk, N. R., Oberhänsli, H., Watts, W. A., Wulf, S., and Zolitschka, B.: Rapid environmental changes in southern Europe during the last glacial period, Nature, 400, 740-743, doi:10.1038/23432, 1999.

Asikainen, C. A., Francus, P., and Brigham-Grette, J.: Sedimentology, clay mineralogy and grain-size as indicators of $65 \mathrm{ka}$ of climate change from El'gygytgyn Crater Lake, Northeastern Siberia, J. Paleolimnol., 37, 105-122, doi:10.1007/s10933-0069026-5, 2007.

Barr, I. D. and Clark, C. D.: Glaciers and climate in Pacific Far NE Russia during the Last Glacial Maximum, J. Quaternary Sci., 26, 227-237, doi:10.1002/jqs.1450, 2011.

Belyi, V.: Structure and formation of the El'gygytgyn Basin (Anadyr Mountains), Geomorphologia, 1, 31-41, 2001.

Belyi, V.: Impactite generation in the El'gygytgyn depression, northeast Russia, as a volcanic phenomenon. 2. On the petrography and geochemistry of the impactites, J. Volcanol. Seismol., 4, 149-163, doi:10.1134/s0742046310030012, 2010.

Belyi, V. and Belaya, B.: Late stage of the Okhotsk-Chukchi Volcanogenic Belt development (upstream of the Enmyvaam River), NEISRI FEB RAS, Magadan, Russia, 108 pp., 1998.

Belyi, V. and Raikevich, M. I.: The El'gygytgyn lake basin (geological structure, morphostructure, impactites, problems of investigation and preservation of nature), NEISRI FEB RAS, Magadan, 27 pp., 1994. 
Bindler, R., Renberg, I., Appleby, P. G., Anderson, N. J., and Rose, N. L.: Mercury Accumulation Rates and Spatial Patterns in Lake Sediments from West Greenland:? A Coast to Ice Margin Transect, Environ. Sci. Technol., 35, 1736-1741, doi:10.1021/es0002868, 2001.

Bloesch, J.: Mechanisms, measurement and importance of sediment resuspension in lakes, Mar. Freshwater Res., 46, 295-304, 1995.

Blott, S. J. and Pye, K.: GRADISTAT: a grain size distribution and statistics package for the analysis of unconsolidated sediments, Earth Surf. Processes Land., 26, 1237-1248, doi:10.1002/esp.261, 2001.

Bortels, H.: Molybdän als Katalysator bei der biologischen Stickstoffbindung, Arch. Mikrobiol., 1, 333-342, doi:10.1007/bf00510471, 1930.

Brigham-Grette, J., Haug, G. H., and Climate Working Group: Climate Dynamics and Global Environments: A Community Vision for the Next Decade in ICDP, Continental scientific drilling: a decade of progress and challenges for the future, 53-94, 2007a.

Brigham-Grette, J., Melles, M., Minyuk, P., and Scientific Party: Overview and significance of a 250 ka paleoclimate record from El'gygytgyn Crater Lake, NE Russia, J. Paleolimnol., 37, 1-16, doi:10.1007/s10933-006-9017-6, 2007b.

Cannon, W. F., Dean, W. E., and Bullock, J. H.: Effects of Holocene climate change on mercury deposition in Elk Lake, Minnesota: The importance of eolian transport in the mercury cycle, Geology, 31, 187-190, doi:10.1130/00917613(2003)031<0187:eohcco>2.0.co;2, 2003.

Cherniak, D. J. and Watson, E. B.: A study of strontium diffusion in plagioclase using Rutherford backscattering spectroscopy, Geochim. Cosmochim. Ac., 58, 5179-5190, 1994.

Cohen, A. S.: Scientific drilling and biological evolution in ancient lakes: lessons learned and recommendations for the future, Hydrobiologia, 682, 3-25, doi:10.1007/s10750-010-0546-7, 2012.

Côté, M. M. and Burn, C. R.: The oriented lakes of Tuktoyaktuk Peninsula, Western Arctic Coast, Canada: a GIS-based analysis, Permafrost Periglac., 13, 61-70, doi:10.1002/ppp.407, 2002.

Cremer, H. and Wagner, B.: The diatom flora in the ultraoligotrophic Lake EI'gygytgyn, Chukotka, Polar Biol., 26, 105114, doi:10.1007/s00300-002-0445-0, 2003.

Cremer, H., Wagner, B., Juschus, O., and Melles, M.: A microscopical study of diatom phytoplankton in deep crater Lake El'gygytgyn, Northeast Siberia, Algological Studies, 116, 147$169,2005$.

Cressie, N. A. C.: Statistics for spatial data, Wiley Series in Probability and Mathematical Statistics, John Wiley \& Sons, 900 pp., 1991.

El Bouseily, A. M. and El Sokkary, A. A.: The relation between Rb, $\mathrm{Ba}$ and $\mathrm{Sr}$ in granitic rocks, Chem. Geol., 16, 207-219, 1975.

Emmermann, R. and Lauterjung, J.: Double X-ray analysis of cuttings and rock flour: a powerful tool for rapid and reliable determination of borehole lithostratigraphy, Scientific Drilling, 1, 269-282, 1990.

Fagel, N., Alleman, L. Y., Granina, L., Hatert, F., Thamo-Bozso, E., Cloots, R., and André, L.: Vivianite formation and distribution in Lake Baikal sediments, Global Planet. Change, 46, 315-336, 2005.

Fedorov, G. and Kupolov, A.: Gas Mercury Survey in the El'gygytgyn Crater, in: The Expedition El'gygytgyn Lake 2003 (Siberian Arctic), edited by: Melles, M., Minyuk, P., Brigham-
Grette, J., and Juschus, O., Reports on Polar and Marine Research, 509, 69-70, 2005.

Fedorov, G., Nolan, M., Brigham-Grette, J., Bolshiyanov, D., Schwamborn, G., and Juschus, O.: Lake El'gygytgyn water and sediment balance components overview and its implications for the sedimentary record, Clim. Past Discuss., 8, 3977-4001, doi:10.5194/cpd-8-3977-2012, 2012.

Francke, A., Wennrich, V., Sauerbrey, M., Juschus, O., Melles, M., and Brigham-Grette, J.: Multivariate statistic and time series analyses of grain-size data in Quaternary sediments of Lake El'gygytgyn, NE Russia, Clim. Past Discuss., 9, 217-244, doi:10.5194/cpd-9-217-2013, 2013.

Fujita, K., Mackey, K. G., McCaleb, R. C., Gubina, L. V., Kovalev, V. N., Imaev, V. S., and Smirnov, V. N.: Seismicity of Chukotka, northeastern Russia, in: Tectonic Evolution of the Bering ShelfChukchi Sea-Arctic Margin and Adjacent Landmasses, edited by: Miller, L., Grantz, A., and Klemperer, S. L., Geol. S. Am. S., 360, 259-272, 2002.

Gasse, F., Vidal, L., Develle, A.-L., and Van Campo, E.: Hydrological variability in the Northern Levant: a 250 ka multi-proxy record from the Yammoûneh (Lebanon) sedimentary sequence, Clim. Past, 7, 1261-1284, doi:10.5194/cp-7-1261-2011, 2011.

Gelety, V., Gapon, A., Kalmychkov, G., Parkhomenko, I. Y., and Kostrova, S.: Mercury in the surficial bottom sediments of lake Baikal, Geochem. Int., 43, 220-226, 2005.

Gelety, V., Kalmykov, G., and Parkhomenko, I.: Mercury in the sedimentary deposits of Lake Baikal, Geochem. Int., 45, 170-177, doi:10.1134/s001670290702005x, 2007.

Glotov, V. Ye. and Zuev, S. A.: Hydrological characteristics of Lake El'gygytgyn, Kolyma, 3-4, 18-23, 1995.

Glushkova, O. Yu.: Geomorphological correlation of Late Pleistocene glacial complexes of Western and Eastern Beringia, Quaternary Sci. Rev., 20, 405-417, doi:10.1016/s02773791(00)00108-6, 2001.

Glushkova, O. Yu and Smirnov, V. N.: Highest Lake Terraces, in: The expedition El'gygytgyn Lake 2003 (Siberian Arctic), edited by: Melles, M., Minyuk, P., Brigham-Grette, J., and Juschus, O., Reports on Polar and Marine Research, 509, 85-88, 2005.

Glushkova, O. Yu. and Smirnov, V. N.: Pliocene to Holocene geomorphic evolution and paleogeography of the El'gygytgyn Lake region, NE Russia, J. Paleolimnol., 37, 37-47, doi:10.1007/s10933-006-9021-x, 2007.

Gurov, E. P. and Gurova, Ye.: Stages of shock metamorphism of silicic volcanic rocks in the El'gygytgyn meteorite crater, Chukotka, Dokl. Acad. Nauk SSSR.: Earth Science subsection, 249, 121123, 1979.

Gurov, E. P., Koeberl, C., Reimold, W. U., Brandstätter, F., and Amare, K.: Shock metamorphism of siliceous volcanic rocks of the El'gygytgyn impact crater (Chukotka, Russia), Geol. S. Am. S., 384, 391-391, 2005.

Gurov, E. P., Koeberl, C., and Yamnichenko, A.: El'gygytgyn impact crater, Russia: Structure, tectonics, and morphology, Meteorit. Planet. Sci., 42, 307-319, 2007.

Halfman, J. D. and Scholz, C. A.: Suspended Sediments in Lake Malawi, Africa: A Reconnaissance Study, J. Great Lakes Res., 19, 499-511, 1993.

Hawley, N. and Lee, C.-H.: Sediment resuspension and transport in Lake Michigan during the unstratified period, Sedimentology, 46, 791-805, doi:10.1046/j.1365-3091.1999.00251.x, 1999. 
Jébrak, M. and Hernandez, A.: Tectonic deposition of mercury in the Almadén district, Las Cuevas deposit, Spain, Miner. Deposita, 30, 413-423, doi:10.1007/bf00196401, 1995.

Juschus, O., Melles, M., Gebhardt, A. C., and Niessen, F.: Late Quaternary mass movement events in Lake El'gygytgyn, North-eastern Siberia, Sedimentology, 56, 2155-2174, doi:10.1111/j.1365-3091.2009.01074.x, 2009.

Juschus, O., Pavlov, M., Schwamborn, G., Preusser, F., Fedorov, G., and Melles, M.: Late Quaternary lake-level changes of Lake El'gygytgyn, NE Siberia, Quaternary Res., 76, 441-451, doi:10.1016/j.yqres.2011.06.010, 2011.

Kelley, S. P., Spicer, R. A., and Herman, A. B.: New Ar-40/Ar-39 dates for Cretaceous Chauna Group tephra, north-eastern Russia, and their implications for the geologic history and floral evolution of the North Pacific region, Cretaceous Res., 20, 97-106, 1999.

Konishchev, V. N.: Characteristics of Cryogenic Weathering in the Permafrost Zone of the European USSR, Arctic Alpine Res., 14, 261-265, 1982.

Koval, P. V., Kalmychkov, G. V., Gelety, V. F., Leonova, G. A., Medvedev, V. I., and Andrulaitis, L. D.: Correlation of natural and technogenic mercury sources in the Baikal polygon, Russia, J. Geochem. Explor., 66, 277-289, 1999.

Koval, P., Udodov, Y., San'kov, V., Yasenovskii, A., and Andrulaitis, L.: Geochemical activity of faults in the Baikal Rift Zone (Mercury, Radon, and Thoron), Dokl. Earth Sci., 409, 912-915, doi:10.1134/s1028334x06060171, 2006.

Layer, P. W.: Argon-40/argon-39 age of the El'gygytgyn impact event, Chukotka, Russia, Meteorit. Planet. Sci., 35, 591-599, 2000 .

Lin, Z. and Puls, R. W.: Adsorption, desorption and oxidation of arsenic affected by clay minerals and aging process, Environ. Geol., 39, 753-759, doi:10.1007/s002540050490, 2000.

Lion, L. W., Altmann, R. S., and Leckie, J. O.: Trace-metal adsorption characteristics of estuarine particulate matter: evaluation of contributions of iron/manganese oxide and organic surface coatings, Environ. Sci. Technol., 16, 660-666, doi:10.1021/es00104a007, 1982.

Lorey, P. and Driscoll, C. T.: Historical Trends of Mercury Deposition in Adirondack Lakes, Environ. Sci. Technol., 33, 718-722, doi:10.1021/es9800277, 1999.

Lozhkin, A. V., Anderson, P. M., Matrosova, T. V., Minyuk, P. S., Brigham-Grette, J., and Melles, M.: Continuous Record of Environmental Changes in Chukotka during the Last 350 Thousand Years, Russ. J. Pac. Geol., 1, 550-555, doi:10.1134/s1819714007060048, 2007.

Melles, M., Minyuk, P., Brigham-Grette, J., and Juschus, O (Eds.).: The Expedition El'gygytgyn Lake 2003 (Siberian Arctic), Reports on Polar and Marine Research, 509, 139 pp., 2005.

Melles, M., Brigham-Grette, J., Glushkova, O. Yu., Minyuk, P. S., Nowaczyk, N. R., and Hubberten, H. W.: Sedimentary geochemistry of core PG1351 from Lake El'gygytgyn - a sensitive record of climate variability in the East Siberian Arctic during the past three glacial-interglacial cycles, J. Paleolimnol., 37, 89-104, doi:10.1007/s10933-006-9025-6, 2007.

Melles, M., Brigham-Grette, J., Minyuk, P., Koeberl, C., Andreev, A., Cook, T., Fedorov, G., Gebhardt, C., Haltia-Hovi, E., Kukkonen, M., Nowaczyk, N., Schwamborn, G., Wennrich, V., and and the El'gygytgyn Scientific Party: The Lake El'gygytgyn Scien- tific Drilling Project - Conquering Arctic Challenges through Continental Drilling, Scientific Drilling, 11, 29-40, 2011.

Melles, M., Brigham-Grette, J., Minyuk, P. S., Nowaczyk, N. R., Wennrich, V., DeConto, R. M., Anderson, P. M., Andreev, A. A., Coletti, A., Cook, T. L., Haltia-Hovi, E., Kukkonen, M., Lozhkin, A. V., Rosén, P., Tarasov, P., Vogel, H., and Wagner, B.: 2.8 Million Years of Arctic Climate Change from Lake El'gygytgyn, NE Russia, Science, 337, 315-320, doi:10.1126/science.1222135, 2012.

Minyuk, P. S., Brigham-Grette, J., Melles, M., Borkhodoev, V. Ya., and Glushkova, O. Yu.: Inorganic geochemistry of El'gygytgyn Lake sediments (northeastern Russia) as an indicator of paleoclimatic change for the last $250 \mathrm{kyr}$, J. Paleolimnol., 37, 123-133, doi:10.1007/s10933-006-9027-4, 2007.

Minyuk, P., Borkhodoev, V. Ya., and Goryachev, N.: Geochemical characteristics of sediments from Lake El'gygytgyn, Chukotka Peninsula, as indicators of climatic variations for the past $350 \mathrm{ka}$, Dokl. Earth Sci., 436, 94-97, doi:10.1134/s1028334x11010181, 2011.

Minyuk, P. S., Borkhodoev, V. Ya., and Wennrich, V.: Inorganic data from El'gygytgyn Lake sediments: stages 6-11, Clim. Past Discuss., accepted, 2013.

Mock, C. J., Bartlein, P. J., and Anderson, P. M.: Atmospheric circulation patterns and spatial climatic variations in Beringia, Int. J. Climatol., 18, 1085-1104, doi:10.1002/(SICI)10970088(199808)18:10<1085::AID-JOC305>3.0.CO;2-K, 1998.

Müller, B., Granina, L., Schaller, T., Ulrich, A., and Wehrli, B.: $\mathrm{P}$, As, Sb, Mo, and Other Elements in Sedimentary $\mathrm{Fe} / \mathrm{Mn}$ Layers of Lake Baikal, Environ. Sci. Technol., 36, 411-420, doi:10.1021/es010940z, 2002.

Nekrasov, I. A.: About the origin and history of the El'gygytgyn Lake basin, Geol. Geofiz., 1, 47-59, 1963.

Nesbitt, H. W. and Young, G. M.: Prediction of some weathering trends of plutonic and volcanic rocks based on thermodynamic and kinetic considerations, Geochim. Cosmochim. Ac., 48, 1523-1534, 1984.

Niessen, F., Gebhardt, A. C., Kopsch, C., and Wagner, B.: Seismic investigation of the El'gygytgyn impact crater lake (Central Chukotka, NE Siberia): preliminary results, J. Paleolimnol., 37, 49-63, doi:10.1007/s10933-006-9022-9, 2007.

Nolan, M.: Analysis of local AWS and NCEP/NCAR reanalysis data at Lake El'gygtytgyn, and its implications for maintaining multi-year lake-ice covers, Clim. Past Discuss., 8, 1443-1483, doi:10.5194/cpd-8-1443-2012, 2012.

Nolan, M. and Brigham-Grette, J.: Basic hydrology, limnology, and meteorology of modern Lake El'gygytgyn, Siberia, J. Paleolimnol., 37, 17-35, doi:10.1007/s10933-006-9020-y, 2007.

Nolan, M., Liston, G., Prokein, P., Brigham-Grette, J., Sharpton, V. L., and Huntzinger, R.: Analysis of lake ice dynamics and morphology on Lake El'gygytgyn, NE Siberia, using synthetic aperture radar (SAR) and Landsat, J. Geophys. Res.-Atmos., 108, 8162, doi:10.1029/2001JD000934, 2002.

Nowaczyk, N. R., Minyuk, P., Melles, M., Brigham-Grette, J., Glushkova, O. Yu., Nolan, M., Lozhkin, A. V., Stetsenko, T. V., Andersen, P. M., and Forman, S. L.: Magnetostratigraphic results from impact crater lake El'gygytgyn, northeastern Siberia: a possibly $300 \mathrm{kyr}$ long terrestrial paleoclimate record from the Arctic, Geophys. J. Int., 150, 109-126, doi:10.1046/j.1365246X.2002.01625.x, 2002. 
Nowaczyk, N. R., Melles, M., and Minyuk, P.: A revised age model for core PG1351 from Lake El'gygytgyn, Chukotka, based on magnetic susceptibility variations tuned to northern hemisphere insolation variations, J. Paleolimnol., 37, 65-76, doi:10.1007/s10933-006-9023-8, 2007.

Oliver, M. A. and Webster, R.: Kriging: a method of interpolation for geographical information systems, Int. J. Geogr. Inf. Syst., 4, 313-332, doi:10.1080/02693799008941549, 1990.

Outridge, P. M., Sanei, H., Stern, G. A., Hamilton, P. B., and Goodarzi, F.: Evidence for Control of Mercury Accumulation Rates in Canadian High Arctic Lake Sediments by Variations of Aquatic Primary Productivity, Environ. Sci. Technol., 41, 52595265, doi:10.1021/es070408x, 2007.

Petschick, R., Kuhn, G., and Gingele, F.: Clay mineral distribution in surface sediments of the South Atlantic: sources, transport, and relation to oceanography, Mar. Geol., 130, 203-229, 1996.

Robinson, C., Shimmield, G., and Creer, K.: Geochemistry of Lago Grande di Monticchio, S. Italy, in: Paleolimnology of European Maar Lakes, edited by: Negendank, J. and Zolitschka, B., Lecture Notes in Earth Sciences, Springer Berlin/Heidelberg, 317-332, 1993.

Sauerbrey, M., Juschus, O., Gebhardt, C., Wennrich, V., Nowaczyk, N., and Melles, M.: Mass movement deposits in the 3.6Ma sediment record of Lake El'gygytgyn, Chukotka, NE Siberia: classification, distribution and preliminary interpretation, Clim. Past Discuss., accepted, 2013.

Schwamborn, G., Meyer, H., Fedorov, G., Schirrmeister, L., and Hubberten, H.: Ground ice and slope sediments archiving late Quaternary paleoenvironment and paleoclimate signals at the margins of El'gygytgyn Impact Crater, NE Siberia, Quaternary Res., 66, 259-272, 2006.

Schwamborn, G., Fedorov, G., Schirrmeister, L., Meyer, H., and Hubberten, H. W.: Periglacial sediment variations controlled by late Quaternary climate and lake level change at Elgygytgyn Crater, Arctic Siberia, Boreas, 37, 55-65, doi:10.1111/j.15023885.2007.00011.x, 2008a.

Schwamborn, G., Förster, A., Diekmann, B., Schirrmeister, L., and Fedorov, G.: Mid- to Late-Quaternary Cryogenic Weathering Conditions at Elgygytgyn Crater, Northeastern Russia: Inference from Mineralogical and Microtextural Properties of the Sediment Record, Ninth International Conference On Permafrost, Fairbanks, 1601-1606, 2008b.

Schwamborn, G., Fedorov, G., Ostanin, N., Schirrmeister, L., Andreev, A., and the El'gygytgyn Scientific Party: Depositional dynamics in the El'gygytgyn Crater margin: implications for the 3.6 Ma old sediment archive, Clim. Past, 8, 1897-1911, doi:10.5194/cp-8-1897-2012, 2012.

Sidorov, A., Chekhov, A., Volkov, A., and Alekseev, V.: Metallogeny of the inner and outer zones of the OkhotskChukotsk volcanogenic belt, Dokl. Earth Sci., 439, 949-954, doi:10.1134/s1028334x11060122, 2011.
Stone, D. B., Layer, P. W., and Raikevich, M. I.: Age and paleomagnetism of the Okhotsk-Chukotka Volcanic Belt (OCVB) near Lake El'gygytgyn, Chukotka, Russia, Stephan Mueller Special Publication Series, 4, 243-260, 2009.

Swann, G. E. A., Leng, M. J., Juschus, O., Melles, M., BrighamGrette, J., and Sloane, H. J.: A combined oxygen and silicon diatom isotope record of Late Quaternary change in Lake El'gygytgyn, North East Siberia, Quaternary Sci. Rev., 29, 774786, doi:10.1016/j.quascirev.2009.11.024, 2010.

Tessier, A.: Sorption of trace elements on natural particles in oxic environments, in: Environmental particles, edited by: Buffle, J. and van Leeuwen, H. P., Lewis Publishers, Chelsea, 425-453, 1992.

Treshnikov, A. F.: Atlas of the Arctic, Main Department of Geodesy and Cartography under the Council of Ministers of the USSR, Moscow, 1985.

Viehberg, F. A., Ülgen, U. B., Damcı, E., Franz, S. O., Ön, S. A., Roeser, P. A., Çağatay, M. N., Litt, T., and Melles, M.: Seasonal hydrochemical changes and spatial sedimentological variations in Lake Iznik (NW Turkey), Quaternary Int., 274, 102-111, doi:10.1016/j.quaint.2012.05.038, 2012.

Vogel, H., Wessels, M., Albrecht, C., Stich, H. B., and Wagner, B.: Spatial variability of recent sedimentation in Lake Ohrid (Albania/Macedonia), Biogeosciences, 7, 3333-3342, doi:10.5194/bg7-3333-2010, 2010.

Vogt, C.: Regional and temporal variations of mineral assemblages in Arctic Ocean sediments as climatic indicator during glacial/interglacial changes, Reports on Polar Research, 251, 1309, 1997.

Vogt, C., Lauterjung, J., and Fischer, R. X.: Investigation of the Clay Fraction $(<2 \mu \mathrm{m})$ of the Clay Minerals Society Reference Clays, Clay. Clay Miner., 50, 388-400, 2002.

Wennrich, V., Minyuk, P., Borkhodoev, V., Francke, A., Ritter, B., Nowaczyk, N., Haltia-Hovi, E. M., Brigham-Grette, J., Melles, M., and El'gygytgyn Science Party.: Pliocene and Pleistocene climate and environmental history of Lake El'gygytgyn/ NE Russia based on high-resolution inorganic geochemistry data, Clim. Past, this issue, in prep., 2013.

Wetzel, R. G.: Limnology : lake and river ecosystems, 3. Edn., Elsevier Academic Press, San Diego, 1006 pp., 2001.

Yanase, W. and Abe-Ouchi, A.: The LGM surface climate and atmospheric circulation over East Asia and the North Pacific in the PMIP2 coupled model simulations, Clim. Past, 3, 439-451, doi:10.5194/cp-3-439-2007, 2007. 